\title{
Teaching Philosophy and Ethics through a Law and Literature Course in Today's Turkey
}

\author{
Special Issue on Active Learning and Teaching in Legal Education \\ Bart van Klink, Hedwig van Rossum, \& Bald de Vries (eds.)
}

E. Irem $A k i^{*}$

\section{Introduction}

Teaching law and jurisprudence is partly about introducing students of law to terms such as rules, morality, principles, equality, validity, value judgments, and justice. These are terms one must digest and learn to use, when necessary, in specific contexts. For example, when a student of law becomes a judge or a practitioner, he or she should know how to act in case of a dilemma or when faced with unjust rules. My argument is that literature, or a law and literature course, can be used as a tool in order to discuss these terms with students.

In this article, drawing on my experience as a lecturer, I discuss how a course on law and literature can contribute to the teaching of legal philosophy. In the first part of the article, I reflect on the nature of the relationship between law and literature ${ }^{1}$ and legal philosophy. I initially relate how the introduction of law and literature to legal school curricula was directly related to debates within legal philosophy and argue that, once these disciplines were accepted into curricula, the content of the course was shaped by each lecturer's approach to law.

In the second part of the article I attempt to answer the question why a legal philosophy course in itself is not sufficient that we feel the need to use literature as well. To answer the question, I discuss what we do with law and literature. My argument is that what we essentially do in the context of the course law and literature is to evaluate people's actions, and this is related to ethics. In this way, I relate legal philosophy to ethics through the use of literature in legal education. In doing so, I explain that my focus on the activity of evaluation in law and literature has also to do with my theoretical background and interests.

In order to evaluate an action we need to be able to see the whole picture, and literature has the potential to provide that ability. Equally, the ability to see the

* Dr. E.I. Aki was a research assistant at Ankara University Faculty of Law until 2017; iremaki@ gmail.com.

1 Unless otherwise stated by law and literature I mean the law and literature course or the law and literature movement. 
whole picture necessitates noting whether the act of evaluation is based on bias and prejudice. In this respect, literature is an efficient means to demonstrate the ways that evaluation built upon prejudice and value judgments leads to unjust results. All the same, can a law and literature course become a tool to liberate law students from implicit value judgments or prejudices? In the last part of this article, I try to answer this question through the experience I gained while teaching law and literature in a state law school in Turkey.

\section{The Relationship between Law and Literature and Legal Philosophy}

The idea that lawyers can learn something from novels goes back to the book list prepared for lawyers' use by Wigmore in 1908 (Gemmette, 1989, p. 285). However, since the publication of James Boyd White's The Legal Imagination in 1973, the law and literature course has emerged as a self-conscious field (Posner, 1986, p. 1352; Ward, 1993, p. 323). The most vigorous time of the movement was in the 1970s and 1980s (West, 2008, p. 1). In 1979 Smith talks about 'a renaissance that will increase the relationship between law and literature' (Smith, 1979, p. 13).

Looking at the history of law and literature and how it became a part of law school curricula, we notice the close relationship between the demand for change in legal education and developments in legal philosophy and theory. While law, politics, and the humanities were once related to each other intellectually and professionally, specialization, technic, and a more utilitarian, or instrumental, approach have started to take their place in legal education (Aristodemou, 1993, p. 161; Gemmette, 1989, p. 289). In this change we see the influence of Bentham's and Austin's works, and in the United States, of Langdell's. The idea that law is a science and must be isolated from other sciences developed from these influences. We should not forget Kelsen's theory as well. While legal positivism has influenced our comprehension of the nature of law and how we teach law, in the 1920s and 1930s American legal realism seriously criticized the then dominant definition of law. These criticisms have continued through critical legal studies, feminist legal theory, and the law and economics movement (Aristodemou, 1993, p. 161-162; Gemmette, 1989, p. 274). Such perspectives challenge the idea that law is a science and an autonomous discipline (Gemmette, 1989, p. 274). Likewise, for Posner, when law and literature ceased to be autonomous disciplines, the law and literature movement came to existence (Posner 2009, p. 5).

The interlocked relationship between law and literature and legal theory is also reflected in the relationship between law and literature and the philosophy of law. The first connection becomes evident if we think that the existence of law and literature or the acceptance of a course of law and literature in law school curricula is directly connected to discussions in legal philosophy. Moreover, once we accept a law and literature course as part of the curriculum, the approach to law adopted by the lecturer shapes the content of the course. The starting point of my law and literature course, as I will explain, bears on my personal approach to legal philosophy, that is, a normative (ethical-based) and critical approach (feminist legal theory). 
The second connection between law and literature and legal philosophy lies in the fact that while the emergence of law and literature is directly related to the debates regarding legal education and legal philosophy, the movement itself, in contrast to, for example, legal positivism and natural law theory, is more preoccupied with legal education. Therefore, while theories such as legal positivism and natural law theory have tried to answer the question What is law?, law and literature enables us to think about alternative approaches to the teaching and study of law (Ward, 1993, p. 323; Weisberg, 2016, p. 37), and especially, legal philosophy.

\section{What Does the Law and Literature Course Offer Us?}

After establishing the connection between law and literature and legal philosophy, let me explain the distinction in law and literature between law as literature and law in literature.

Law as literature is about reading and interpreting legal texts through literary criticism; that is, it is about the interpretation of law (Dunlop, 1991, p. 63; Gemmette, 1989, p. 293-294). Therefore, law as literature is related to the central topics of legal philosophy such as indeterminacy and interpretation.

As for law in literature, it focuses on literary works related to law, works that include stories about court trials, lawyers, judges, prosecutors, and so on (Dunlop, 1991, p. 63). Those participating in the course read and discuss these works, their characters, and the trials described in them. Literary works are useful tools in explaining the concepts of legal philosophy (Smith, 1979, p. 20; Dunlop, 1991, p. 64), as questions about the nature and aim of legal systems can be discussed through their reflection in literature. For example, natural law, positive law, fidelity to law, justice, revenge, power, order, hierarchy, freedom of will are all concepts both legal theory and literature are interested in (Aristodemou, 1993, p. 168). Moreover, as Weisberg argues, 'literary art about law is richer, if not more important, than most other jurisprudential sources' (Weisberg, 1989, p. 1598, quoted in Aristodemou, 1993, p. 170).

After having stated that literature is a useful tool in teaching legal philosophy, this question is inescapable: What exactly are we doing when we teach law and literature? Why is the course of legal philosophy not sufficient so that we need to use literature as well? In other words, how do we, as legal scholars, differ from scholars of literature? What is the relevance of literary criticism to the legal education that lawyers receive? (Dunlop, 1991, p. 64) I asked myself these questions and realized that what we do in law and literature is to evaluate the actions of persons in fiction. In other words, what we do within the framework of law in literature, even if not passing judgments like a judge, is an act of evaluation. We evaluate the characters and the acts of characters in the literary works we read: the acts of Mersault and the acts of those judging Mersault, Antigone, Kreon, and so on. What we do through literature is to show students the activity of evaluationwhat we should or should not consider when we evaluate the acts of persons.

However, evaluation and adjudication are topics of legal philosophy as well. Evidently, there is a huge literature about adjudication in legal philosophy. In 
addition, in courses such as criminal and civil law, students study how to apply rules to particular cases. So what does law and literature contribute to students and lecturers about the evaluation activity that legal philosophy does not?

When we evaluate persons and actions through literature we have the opportunity to know the complete picture. Evaluation, in fact, requires comprehending through contextualization (Kucuradi, 2013, p. 58). So, literature enables us to grasp the actions of actors within a context as a whole (Iyi, 2014, p. 150). It also enables us to deeply know the person who acts and understand why he or she acts in this or the other way. Does the person act according to value judgments, political interests, or religious convictions? Does she or he act according to ethical principles, although she or he does not do the right thing in that or the other particular situation? Unfortunately, the study of legal textbooks and precedents does not provide such knowledge. The analysis of judicial precedents in legal education aims to prepare legal students for the practice of law, but it does not give them the whole picture. In practice, even when law students become lawyers, prosecutors, or judges, they cannot easily comprehend the whole picture. Through law and literature, we can offer a more complete picture. We can likewise demonstrate how knowing the whole picture is crucial in order to arrive at a right decision in each particular and unique case. Moreover, we make students think about the difference between "the question "What is the right action?" and the question "What is the right thing to do in this situation?"' (Kucuradi, 2009, p. 25). At least, through conveying this knowledge, we may expect students to feel the need to endeavour to reach right decisions in their professional life.

In addition, literature provides an alternative and fascinating window into human actions and human possibilities (Iyi, 2014, p. 150; Kucuradi, 2014, p. 29). As Weisberg writes, '[n]ovels about law ... are paths to human understanding' (Weisberg, 1988, p. 121, quoted in Ward, 1995, p. 9). What is more, literary works also present diverse lawyers, attorneys, judges, and prosecutors, allowing us to evaluate their actions in law and literature.

In short, what we perform in law and literature is the activity of evaluation. To analyse and evaluate human action and to explicate the value of action is an activity clearly related to ethics (Kucuradi, 1988, p. 34; Pieper, 2012, p. 17-18). However difficult, we can reach the knowledge of ethical relations by looking at people and moving around the realm of literary works (Kucuradi, 2006, p. 4). Drawing on Nussbaum's argument that 'the novel constructs a paradigm of a style of ethical reasoning that is context-specific' (Nussbaum, 1995, p. 8), I relate legal philosophy and ethics through the example of the use of literature in legal education, more specifically the course of law and literature. In short, I use literature as a tool in teaching legal philosophy. And by employing literature's relationship to ethics, as it facilitates people to think deliberately on action, I establish a connection between legal philosophy and ethics.

As stated earlier in this article, I argue that each lecturer's approach to the concept of law determines the character of her law and literature course. In my case, I come from an academic tradition of legal philosophy heavily based on ethics. Nevertheless, when I was preparing my syllabus, I did not deliberately plan a literature course related to ethics. Yet, I realized that the literary works and topics 
I had chosen eventually brought me to a course related to ethics. This was obviously due to my (academic) background. On the basis of this, the content of my law and literature course was mostly related to problems of evaluation. I tried to show students that evaluations based on value judgments and prejudices lead to unjust results. So the following questions became important: Can law and literature become a tool to liberate law students from value judgments and prejudices? While we teach our students, for example, the Hart-Dworkin debate, which is related to legal indeterminacy and hard cases, can we prepare them to deal with situations regarding obviously unjust cases based on value judgments or prejudices? More clearly, do students receive an education that will enable them to think beyond the value judgments of the society they live in?

In the following pages I will try to answer these questions through the experience I gained while teaching law and literature.

\section{My Law and Literature Course ${ }^{2}$}

As explained, the theme I chose was the influence of prejudices upon decision making and evaluation. I organized the syllabus and reading material accordingly. The learning goal of the course was to make students conscious of the danger of making unjust decisions when prejudices influence our evaluation.

To do this, I first gave a lecture in order to introduce and discuss concepts such as value judgments, prejudices, and the distinction between critical and positive morality. I gave students reading assignments about morality and value judgments written by scholars of legal studies and ethics. So, students gained some idea about these concepts, which we then discussed through literary works. As explained, I see a serious connection between law and literature and legal philosophy. I believe students need some theoretical knowledge about issues of morality, value judgment, and so on. Yet, I realized that students do not think the same way. Therefore, instead of having an introductory lecture on theory, I decided that the theory I wanted to introduce to students should be embedded in each weekly discussion of literary work.

As for the reading list, my argument is that the relationship between law and literature and politics shapes the reading list of each lecturer. Let me explain this

2 Here, I would like to provide some basic information about the system of legal education in Turkey. In Turkey, students enrol in law schools in accordance with the score they achieve in the countrywide general university entry exams (multiple choice exam) organized each year by a central state institution. Law school lasts four years. Courses on the philosophy and sociology of law are generally taught in the third year. Courses on law and literature are slowly becoming a part of law school curricula as elective courses. In the law faculty where I delivered the lecture, law and literature is a second year elective course. Third and fourth year students can take the course as well, if they wish. Philosophy of law is a third year compulsory course. Students, thus, come across some concepts of legal philosophy initially in their second year of studies through law and literature. In other words, they first come to know concepts of legal philosophy without having taken the philosophy of law course. 
by establishing a three-sided relationship between law and literature and politics. The first one is the relationship between your course and the country you live in. The issue is how the political atmosphere in the country affects you and your course. The second one is related to the fact that the law and literature course itself reflects a political view. More specifically, your own political choices or your background determines which literary work will be included in the syllabus. Here, I do not refer to plain political choices, such as the political party you vote for. Certainly, such a choice will not determine the syllabus. Most lectureres would follow a mainstream syllabus, with classical readings such as Crime and Punishment, The Stranger, The Merchant of Venice, and so on. But my point is that only if you are sensitive towards, for example, memory or your country's recent past or gender issues, the syllabus will be beyond the ordinary or mainstream.

The third relationship between the course and politics comes up with the political views of students. The interaction between these three determines the content of the course. For example, in a classroom that includes many or some conservative students, how would a discussion on gay-and-lesbian literature resonate? Will it be easy for any lecturer to initiate and direct discussions? How do conservative students react to literary works that go against conventional value judgments about women? How would conservative and nationalist students react to literary works about minorities that fall outside the canon of nationalist literature? How does being a young female lecturer affect the course discussions? The political atmosphere in Turkey was (and continues to be) very tense, to say the least, and this is reflected in the academia and even inside the classroom. For this reason, I could only follow a predominantly mainstream syllabus. Yet, due to my background and interest in gender issues, in one semester I prepared a syllabus that included gender as a literary theme. ${ }^{3}$ In short, we read a number of novels by Turkish and foreign writers (To Kill a Mockingbird, The Stranger, The Reader), some explicitly dealing with gender (Antigone, Asilacak Kadin).

In addition to literary works, I included one film for each semester: Twelve Angry Men by Sidney Lumet and Conviction by Tony Goldwyn. I thought it suitable to have students watch films for practical reasons - to accustom and give them time to read the rest of the books on the reading list.

At the beginning I asked students to prepare presentations. In their presentations students gave information about each work, writer, and the period the work had been written in. Students who presented were quite pleased. But this situation caused an unintended outcome: Some students, instead of reading the books, preferred to listen to the presentations about them. On the other hand, those who read the books said that rather than listening to presentations, they preferred to discuss the literary works. I think they thus showed their preference for a course

3 My reason for choosing this topic was again related to my background. I have been sensitive to gender issues since the time I was an undergraduate student. Moreover, in the department I did my $\mathrm{PhD}$, feminist legal theory receives wide acceptance. There are postgraduate courses and several PhD students working on feminist jurisprudence. Moreover, there is a women's studies center next to our faculty building. I had a chance to follow several courses there during my $\mathrm{PhD}$ studies. So, my background again determined the content of my course. 
that would be different from the usual law school course where the lecturer is the only one talking and the students just listen. Therefore, I abandoned the idea of having students make presentations and instead concentrated on class discussions of the assigned readings.

I did not take attendance. Therefore, only those students who were really interested attended. They participated in the discussions actively and read the books with pleasure. I think they were very pleased to read something apart from law books. The atmosphere in the classroom was friendly. However, not taking attendance brought another issue: The students who did not attend the course were the students most likely in need of a more critical view. Since this course depended on discussion and participation, students needed to come to the course intentionally. Moreover, the number of enrolled students was too high. In case all of them attended the course, the discussions and participation would be practically impossible, and thus, the lecturer would have no option but to lecture from the stand.

As for grading, there was a written exam since the number of enrolled students was high. The exam was not very demanding. I did so deliberately because I wanted them to be free of the worry of getting a high score and just attend the class discussions. The exam questions were related to the learning goal of the course. I asked students to find the problematic points in the court trials in the literary works we had read, that is, the prejudices. Results were fine. Even students who did not attend the course regularly got good results since I gave them reading material about the literary works. But if I had not given them, students who had not attended the course would probably not have properly answered the questions. This shows that most of the students, even if they did not attend the classes, followed the reading list.

I started each course with a summary of the assigned literary work. I did not summarize the literary works myself, but requested students to do so. I proceeded step by step through questions and was careful not to talk too much. I wanted the students to actively participate in the classroom discussions, which they did. So, I acted more as a moderator and raised questions instead of replying to questions. As students tried to answer the questions and dwell on how prejudices affected the result, they participated more than what they usually do in courses of legal philosophy.

I should admit here that there are certain risks with this method. When you proceed through questions, the discussion could lead the debate into directions the lecturer did not intend. We should also consider the possibility of heated discussions among students, which is an undesirable result for sure, as sometimes students can be very harsh with each other. In this respect, the lecturer always has to keep the balance. Yet, this course could serve as a means to teach students how to debate, listen to, and talk to each other, which is not something they typically learn in the Turkish educational system. For example, when we discussed Antigone, the most notable point came from a few conservative Muslim students. Their attention was immediately attracted by the fact that Antigone's refusal to obey Kreon's order was justified on the basis of Kreon's violation of the commandments of religion. I had to direct the debate in an impartial way, considering the tension between secular and conservative Muslim students. 
In short, I chose the theme of the course and prepared in advance questions that would compel students to participate and debate. I informed students of the theme at the beginning of the semester, but they did not know the questions in advance. I did so because I was afraid that the students would not try to think critically or prepare themselves for debate but rather attempt to find the one single answer the same way they prepare for the exams. I conducted the discussions within the framework of the theme and the questions I had prepared.

I will now explain the way we discussed the themes by means of three examples from the syllabus. For instance, in the discussion of The Stranger we focused on value judgments about the proper way someone should behave after his mother's death. We deliberated on The Stranger on the basis of how value judgments that pervade society could determine our opinions about the person who is judged (Aki \& Zaluski, 2012, p. 94). We discussed how a person can be seen as a villain if he does certain things that are not socially accepted, such as drink coffee or smoke in front of his mother's dead body, or even to appear walking with a woman after the funeral. Of course, The Stranger is not a book to be solely discussed within the framework of prejudices (Aki \& Zaluski, 2012, p. 93-98). For example, Mersault's alienation from the society he lived in could be a topic for discussion as well. But our main theme was value judgments. More clearly, my primary aim was to show that when prejudices become the criteria for evaluating an act, such evaluation could result in unjust decisions, in Mersault's case the death penalty. Value judgments or 'social conventions unrelated to his crime played an important role in passing this sentence' (Aki \& Zaluski, 2012, p. 94). In Mersault's case, the students were sure that value judgments should not determine our decisions about the person who is judged.

Another issue we debated about this novel was the degree to which we need to know a person in order to evaluate his or her actions. Issues such as who is the judged and why he or she acted that way are important for any trial. But where is the borderline? Why was it important whether Mersault smoked next to his mother's coffin? I suppose we cannot find answers to these questions in the French Code of Criminal Procedure or any code of criminal procedure. Posner, in contrast, states that French law is very open with regard to evidence of bad character (Posner, 2009, p. 62). But the thing we should do is to show students that the content of bad character should not be related to value judgments, clichés, and prejudices. As a result of the class discussions, students became aware of the difficulty of defining a clear borderline.

With To Kill a Mockingbird our main theme was again prejudices. We dwelt on the question of how it is possible for a person, whose innocence can be demonstrated, to be seen as guilty solely through the influence of value judgments, or in other words, how prejudices cause injustice. Following Uygur, I drew on Miranda Fricker and introduced the concept of epistemic injustice in our discussions of the novel To Kill a Mockingbird. ${ }^{4}$ I gave students Uygur's text about Fricker's concepts 
so that they would have some knowledge about the concept of epistemic injustice. Fricker divides epistemic injustice into testimonial injustice and hermeneutical injustice as follows:

Testimonial injustice occurs when prejudice causes a hearer to give a deflated level of credibility to a speaker's word; hermeneutical injustice occurs at a prior stage, when a gap in collective interpretive resources puts someone at an unfair disadvantage when it comes to making sense of their social experiences. An example of the first might be that the police do not believe you because you are black; an example of the second might be that you suffer sexual harassment in a culture that still lacks that critical concept. We might say that testimonial injustice is caused by prejudice in the economy of credibility; and that hermeneutical injustice is caused by structural prejudice in the economy of collective hermeneutical resources. (Fricker, 2007, p. 1)

A good example to grasp the meaning of testimonial injustice can be found in To Kill a Mockingbird when the jury refuses to believe Tim Robinson's words. Although Tim Robinson insists that he did not rape Mayella and Atticus proves it with evidence, their words fall on deaf ears (Fricker, 2007, p. 23-26). The inability or refusal to hear or acknowledge testimony causes legal injustice (Fricker, 2012, p. 293). As a result of the literature and the discussions in class, students were able to grasp the legal injustice Tim Robinson faced.

One more point I would like to state about To Kill a Mockingbird is that of some students' admiration of Atticus. Apart from admiring him as a lawyer, their interest was aroused by his ability to do the right thing in every situation and not commit any mistake. This is a good example of how literary works can have an effect specifically on prospective lawyers.

Another novel in the syllabus was Asilacak Kadin by Pınar Kur. In this novel we read the story of Melek. The novel has three parts: The first part presents the thoughts of the chief judge in Melek's case. The second part presents Melek's thoughts, and the last part presents the thoughts of the boy who actually killed Melek's husband. Melek was forced to have sex with men from the neighbourhood by her own husband, a rich man who owned a waterfront house. Before marrying him, Melek had lived in that house as a handmaiden since her childhood. The owner of the house married her in order to easily sell her to men from the neighbourhood and watch them during intercourse. The son of an employee of the house fell in love with Melek and then killed her husband. But Melek was also prosecuted. During the judicial investigation and proceedings, she did not utter a word. Till that day she had seen violence from all those surrounding her and yet nobody had ever heard her. She was not familiar with the language of the trial and its rules. So why should she talk? What made this book important to our course was Melek's silence, and even more, the judge's reaction to her silence. Here, we discussed the issue again through Fricker's concept of the two aspects of silence-positive and negative. 'In the negative aspect, there is the imposed silence of those who are in some way prevented from making their voices heard. This kind of silence is 
normally effected by way of an injustice' (Fricker, 2012, p. 287). Melek's voice was silenced. Melek had never been outside the waterfront. She had no idea how to communicate with people, especially with prosecutors and judges. Her voice was silenced by the same judges who had to listen to her. The chief judge was sure about her guilt because she did not talk. According to him, if someone does not talk in the courtroom, it means that she or he is guilty. He based his conviction on the cliché 'silence gives consent' (Uygur, 2013, p.158).

As for the positive aspect of silence, it requires listening to the person who talks. 'This kind of silence belongs with a moral attitude of attention to others-an openness to who they are and what they have to say' (Fricker, 2012, p. 287). In the story, only one judge, the only female judge, tried to understand Melek's silence. Another point we discussed in this novel was the silence of the neighbourhood. We used the concept of passive injustice. As Judith Shklar argues,

[p]assive injustice refers strictly to the failures of citizens, especially in republics, to fulfill their public responsibilities. For them it should not be enough to wait around until the agencies of government act when a public wrong has been committed. (...) The normally unjust man is guilty of unfairness and of actively violating law and custom. The passively unjust man, however, does something else. He is simply indifferent to what goes on around him, especially when he sees fraud and violence. His failure is specifically as a citizen. It is not a matter of lacking general goodness. When he sees an illegal action or a crime, he just looks the other way. (Shklar, 1989, p. 1142)

Even if the inhabitants of the neighbourhood knew about the violence, physical and sexual, inflicted upon Melek, they did not try to help her or report to the police.

In Melek's case, students felt sorry for her. I can say that some of them became angry. On the other hand, there was a small discussion about the boy who killed the husband. Did he really fall in love with Melek or not? In the novel, the boy had sex once with Melek in front of the husband. According to some students, if he really loved her, he would not have done such a thing. Other students reacted to the killing of the husband. For them, this was not a solution for Melek. The boy should have found some other way out.

\section{Concluding Remarks}

I have tried here to transmit my experience of teaching the course law and literature in a law school in Turkey. It was inspiring to see that the students responded in a positive way. They became more aware and sensitive of gender issues, the importance of human rights, and the concept of equality before the law. There may not have been heated discussions in the classroom, but a nerve was touched. I think the reason was that most students were already, implicitly, sensitive to these issues. Another reason could be, as I said before, that I followed a partly 
mainstream syllabus. In other words, we did not discuss issues that are controversial in Turkey but through addressing these more general issues, students themselves were able to relate to controversial issues in Turkey and develop a more critical attitude than before.

When I was preparing the syllabus, my learning goal was to make students think about the activity of evaluation and to make them conscious of the important role value judgments unconsciously play when people evaluate other people and circumstances. In order to make just decisions as legal professionals, being conscious about the activity of evaluation and value judgements is extremely important. The taking of just decisions as secured by the minimum necessities of the rule of law, such as equality in front of the law as a citizen, is one of the assets of any peaceful society. In fact, through the law and literature course, I tried to show students the opposite picture, such as that depicted in To Kill a Mockingbird.

In their professional life as judges or lawyers, students will struggle with prejudices of colleagues and clients. Perhaps they will struggle with their own prejudices. If they struggle with their own and other people's prejudices, I think this course would have achieved its aim. For me it was rewarding to see such a struggle during the course. For example, we read the book Intibah by Namik Kemal. This is an old novel originally published in 1876 and written in a heavily gendered language. In the novel women are depicted as either good and honourable or bad and dishonourable. What is more, there are good men harmed by these immoral women. My aim with this reading was to make students conscious of gendered language and biases and clichés against women. In the class some female students immediately criticized the novel. Following the discussion in the classroom, some male students became more conscious of gendered clichés and biases in their evaluation of other people. But some questions are still inescapable: What did this course contribute to students' development? Were there great changes to their world views? Did they become more moral persons? Do they not just worry about their grades and careers now?

These questions are linked to the limitations and the potential of the law and literature course. After all, with this course we do not re-create the students from scratch and return them to society as moral individuals. But we do show them the potential of human beings and the situations and dilemmas they face. And this is way beyond what legal textbooks can do.

At the end of the semester, one of my students told me that she used to want to be a judge, but she had changed her mind after our course. When I asked why, she told me that she had realized that in some circumstances it is really hard to come to a decision. To avoid such an outcome, the course must make students conscious that to have a critical view is an essential part of being a good judge. My aim, of course, was not to dissuade students from becoming judges. My aim was to show that making such kinds of difficult decisions requires the activity of evaluation. Evaluating the acts of others is a complicated act that requires knowledge of the whole picture and the solution to that is not to be found solely in norms, legal codes, and precedents. During the course, students, instead of memorizing legal codes and normative texts, came to reflect on how the legal system works in practice and evidently became more conscious of their professional identity-what it 
might entail to be a judge or a defence attorney. In this respect, the course was successful. Here lies the significance of law and literature for legal education, as it provides students with perspectives and understanding regarding their profession they usually do not find in the law studies curriculum.

\section{Postscript}

My law and literature course adventure was quite short: I delivered this course only for three semesters. I was then dismissed from the university for being a peace academic and could not teach the course any more.

\section{References}

Aki, E. Irem \& Zaluski, W. (2009). Pathologies of legal reasoning or legal reasoning as a pathology? Two interpretation of the stranger. In: T. Bustamante \& O. Onazi (Eds.). Proceedings of the $24^{\text {th }}$ World Congress of the International Association for Philosophy of Law and Social Philosophy, Beijing, vol II. ARSP Beiheft 131, 93-98.

Aristodemou, M. (1993). Studies in law and literature: Directions and concerns. Anglo-American Law Review, 22(2), 157-193.

Dunlop, C.R.B. (1991). Literature studies in law Schools. Cardozo Studies in Law and Literature, 3(1), 63-110.

Fricker, M. (2007). Epistemic injustice: Power and the ethics of knowing. Oxford: Oxford University Press.

Fricker, M. (2012). Silence and institutional prejudice. In: S.L. Crasnow \& A.M. Superson (Eds.). Out from the shadows: Analytical feminist contributions to traditional philosophy (pp. 287-306). New York: Oxford University Press.

Gemmette, E. Villiers (1989). Law and literature: An unnecessarily suspect class in the liberal arts component of the law school curriculum. Valparaiso University Law Review, 23(3), 267-340.

Iyi, S. (2014). Edebiyatin Ici Felsefenin Disi. In: M. Gunay \& A. Osman Gundogan (Eds.). Felsefe ve Edebiyat (pp. 143-156). Konya: Cizgi Kitabevi.

Kucuradi, I. (1988). Uludag Konusmalari. Ankara: Turkiye Felsefe Kurumu Yayini.

Kucuradi, I. (2006). Etik. Ankara: Turkiye Felsefe Kurumu Yayini.

Kucuradi, I. (2009). Dialog: Between whom, on what?. In: I. Kucuradi (Ed.). Papers of the 2007 World Philosophy Day (pp. 23-29). Ankara: Turkiye Felsefe Kurumu Yayini.

Kucuradi, I. (2013). Sanata Felsefeyle Bakmak. Ankara: Turkiye Felsefe Kurumu Yayini.

Kucuradi, I. (2014). Deger, Degerler, Yazin, In: M. Gunay \& A. Osman Gundogan (Eds.). Felsefe ve Edebiyat (pp. 11-30). Konya: Cizgi Kitabevi.

Nussbaum, M.C. (1995). Poetic justice: The literary imagination and public life. Boston: Beacon Press.

Pieper, A. (2012). Etige Giris. Istanbul: Ayrinti Yayinlari.

Posner, R.A. (1986). Law and literature: A relation reargued. Virginia Law Review, 72(8), 1351-1392.

Posner, R.A. (2009). Law and literature. Cambridge, Mass.: Harvard University Press.

Shklar, J. (1989). Giving injustice its due. The Yale Law Journal, 98(6), 1135-1151.

Smith, J.A. (1979). The coming renaissance in law and literature. Journal of Legal Education, 30(1/2), 13-26. 
Uygur, G. (2013). Hukukta Adaletsizligi Gormek. Ankara: Turkiye Felsefe Kurumu Yayini.

Uygur, Gulriz (2015). Adaletsizligi Edebiyat Eserlerinde Gormek. www.t24.com.tr/k24/ yazi/adaletsizligi-edebiyat-eserlerinde-gormek-bilgisel-epistemik-adaletsizlik-vedertlenerek-ilgilenmek,175 (last accessed 14 June 2018).

Ward, I. (1993). The educative ambition of law and literature. Legal Studies, 13(3), 323-331.

Ward, I. (1995). Law and literature: possibilities and perspectives. Cambridge: Cambridge University Press.

Weisberg, R. (1988). Coming of age some more: 'Law and literature' beyond the cradle. Nova Law Review, 13(1), 107-124.

Weisberg, R. (1989). Entering with a vengeance: Posner on law and literature. Stanford Law Review, 41(6), 1597-1626.

Weisberg, R. (2016). What remains 'real' about the law and literature movement?: A global appraisal. Journal of Legal Education, 66(1), 37-43.

West, R. (2008). Literature, culture, and law - at Duke University. Georgetown Law Faculty Working Papers No. 75, pp. 1-29. www.scholarship.law.georgetown.edu/fwps_ papers/75 (last accessed 14 June 2018). 